\title{
Prenatal Exposure to Ethanol in Rats: Effects on Postnatal Maturation of the Small Intestine and Liver
}

\author{
JEAN-PAUL BUTS, ETIENNE M. SOKAL, AND FRANCOIS VAN HOOF \\ Laboratories of Pediatric Gastroenterology, Pediatric Hepatology, and Physiological Biochemistry, Faculty of \\ Medicine and the International Institute of Cellular and Molecular Pathology, University of Louvain, \\ Brussels, Belgium
}

\begin{abstract}
To examine the effects of prenatal exposure to ethanol on postnatal development of small intestinal and liver functions, female rats were accustomed to increasing amounts of ethanol (10 to $25 \%$, vol/vol) in tap water for 1 mo. During pregnancy, ethanol-fed dams had higher daily caloric intake and similar weight gain compared with controls. In ethanol offspring, neonatal mortality was $\mathbf{2 8 . 9} \%$ compared to $0 \%$ in controls. Although ethanol had been withdrawn at birth, pups issued from ethanol-treated mothers showed at 5 and $10 \mathrm{~d}$ postpartum decreased values of body weight, jejunal and ileal weights, and intestinal DNA concentration per unit of length, as well as lower specific and total activities in lactase and maltase, compared with controls. DNA synthesis rates, measured by the incorporation of $\left[{ }^{3} \mathrm{H}\right]$ thymidine into mucosal DNA, were also significantly $(-20$ to $-34 \%, p<0.01)$ depressed in the jejunum and ileum of ethanol pups at 5 and $10 \mathrm{~d}$ of age. All these parameters returned to control levels by d 15 postpartum. Electron microscopy of jejunal mucosal samples at 5, 10, and $15 \mathrm{~d}$ of age revealed that ethanol pups differed from controls by a fetal-like immature aspect of the enterocytes, which persisted up to $d 15$. The ontogenic upsurge in sucrase and the decline in lactase occurred at weaning with the same chronology in both groups, but the level reached by sucrase activity was about $50 \%$ lower in alcohol offspring than in controls. Except for moderate steatosis, the ultrastructure of hepatocytes was unaltered in sucklings. The acinar zonal distribution and the postnatal changes in the liver microsomal enzymes, glucose-6phosphatase and NADPH-dehydrogenase, remained similar in ethanol and control groups. These data indicate that exposure of rats to ethanol during pregnancy can affect postnatal development of intestinal functions originating in utero, even though ethanol is withdrawn at birth. Consequently, persistence of intestinal injury after birth could play a role in the genesis of failure to thrive and malnutrition observed in infants with fetal alcohol syndrome. (Pediatr Res 32: 574-579, 1992)
\end{abstract}

Abbreviations

FAS, fetal alcohol syndrome

Received November 29, 1991 ; accepted June 18, 1992

Correspondence and reprint requests: Jean-Paul Buts, M.D., Ph.D., Department of Pediatrics, Clinique St-Luc, 10 Av. Hippocrate, B-1200 Brussels, Belgium

Supported by Grants No. 5242-01 and 6.242.01/3-4510-89 from the "Fonds de la Recherche Scientifique Medicale" (FRSM) from the U.S. Public Health Service (NIH-DK 9235) and from the FDS "Fonds de Developpement Scientifique" de l'Universite Catholique de Louvain.
In man and mammals, chronic alcoholism is a well-known cause of gastrointestinal and hepatic disturbances leading to gastritis, pancreatitis, chronic diarrhea, impaired intestinal absorptive functions, malnutrition, and liver cirrhosis (1-3). Newborns issued from chronic alcoholic mothers often exhibit multiple birth defects that are termed "fetal alcohol syndrome." In its full clinical expression, FAS consists of a distinctive pattern of facial and visceral abnormalities, growth retardation, and brain lesions or dysfunctions $(4,5)$. However, not all children prenatally exposed to ethanol are born with FAS, even though their mothers had consumed comparable amounts of ethanol during pregnancy, and a great variety of incomplete forms of FAS have been reported $(6,7)$. Accumulating experimental $(8,9)$ and clinical evidence (10) indicates that, beside the daily amount of alcohol ingested, the duration of maternal alcohol illness plays a determinant role in the frequency and severity of embryofetopathies and birth defects. Although several experimental models of chronic alcoholism have been developed in pregnant animals to study intrauterine growth and the occurrence of FAS in the progeny $(8-12)$, the relationship between chronic alcohol intake during pregnancy and the quality of postnatal growth has been little investigated (13). In particular, it remains unknown whether ethanol consumption during gestation may alter postnatal maturation of gastrointestinal and liver functions originating in utero.

The present study was designed to examine the postnatal maturation of small intestine and liver functions in offspring issued from rats that were exposed to ethanol during parturition and gestation, ethanol being withdrawn at birth.

\section{MATERIALS AND METHODS}

Animals and alcohol administration. Twelve female Wistar rats, $50 \mathrm{~d}$ old, weighing between 150 and $170 \mathrm{~g}$ were housed individually in metabolic cages and were acclimatized during 2 wk to controlled conditions of temperature $\left(21 \pm 1^{\circ} \mathrm{C}\right)$, humidity $(60 \%)$, and light-dark cycle $(12 \mathrm{~h})$. All animals were provided with food pellets (Diet 103, UAR, Villemoisson-sur-Orge, France) and water ad libitum.

The method of Testar (14) was used to induce chronic alcohol consumption. Briefly, females rats $(n=6)$ were accustomed to alcohol by increasing weekly ethanol concentration in drinking tap water $(10,15,20$, and $25 \%$ ethanol $(\mathrm{vol} / \mathrm{vol})$ over a period of $4 \mathrm{wk}$ ). Control rats $(n=6)$ received tap water only. After 1 mo of treatment, female rats in proestrus or initial estrus were placed overnight with intact males of the same strain. Pregnancy was presumed by the detection of a vaginal plug. This finding was considered as an index of $\mathrm{d} 0$ of gestation. Pregnant females were replaced individually in their cages and assigned again to ethanol $25 \%(\mathrm{vol} / \mathrm{vol})$ in drinking water as the sole source of liquid with food ad libitum. During pregnancy, experimental ( $n$ 
$=5)$ and control $(n=5)$ pregnant rats were monitored daily for body weight, calorie intake, and liquid consumption.

On the day of delivery, ethanol was withdrawn and replaced by tap water. The litters of ethanol-treated rats and control rats were reduced to eight pups per litter and pups were assigned at random to be nursed by a control or an ethanol-fed mother to equalize postnatal conditions of feeding and milk supply. During the suckling period, the pups had free access to the nipples.

Offspring from ethanol-treated and control females were killed at different postnatal ages: during the suckling (d 5, 10, and 15) and weaning periods (d 25 postpartum).

Preparation of specimens and tissues. For intestinal enzyme assays, the pups were killed at $0730 \mathrm{~h}$ without fasting. At this time of the day, the activity of microvillous enzymes that show a circadian rhythm, such as disaccharidases, is elevated and varies little from animal to animal (15). On the day of the experiment, pups were killed by decapitation. The entire small intestine from the ligament of Treitz to the ileocecal valve was excised immediately, rinsed in ice-cold saline, weighed, measured under fixed tension, and divided into two equal segments.

The proximal segment was defined as the jejunum and the distal segment was defined as the ileum. Each segment thereafter was opened longitudinally, rinsed in ice-cold saline, blotted on filter paper, and weighed. For assays, the mucosal layer of both jejunum and ileum was removed by scraping between glass slides, wrapped in Parafilm (American National Can, Greenwich, CT), and stored in liquid nitrogen until use. For light microscopy, tissue specimens (proximal $2 \mathrm{~cm}$ of each jejunal and ileal segment) were fixed in $10 \%$ formaldehyde, sectioned, and stained

Table 1. Morphometric parameters measured in 5-d-old pups issued from ethanol-treated mothers and controls

\begin{tabular}{|c|c|c|c|c|}
\hline \multirow[b]{2}{*}{ Parameter } & \multicolumn{2}{|c|}{ Day 5 postpartum* } & \multirow[b]{2}{*}{$\Delta(\%) \dagger$} & \multirow[b]{2}{*}{$p \ddagger$} \\
\hline & Controls & Ethanol & & \\
\hline Animals $(n)$ & 8 & 8 & & \\
\hline Body wt (g) & $12.4 \pm 0.69$ & $10.2 \pm 0.82$ & -18 & $<0.005$ \\
\hline Liver wt (mg) & $340 \pm 27$ & $311 \pm 19$ & -9 & $<0.0125$ \\
\hline Kidney wt (mg) & $156 \pm 9.8$ & $115 \pm 10$ & -26 & $<0.005$ \\
\hline Intestinal wt (mg) & $517 \pm 32$ & $447 \pm 69$ & -14 & $<0.01$ \\
\hline Intestinal length $(\mathrm{cm})$ & $31.2 \pm 3.0$ & $29.1 \pm 3.2$ & -7 & NS \\
\hline \multicolumn{5}{|l|}{$\begin{array}{l}\text { Intestinal DNA } \\
\quad(\mathrm{mg} / \mathrm{cm})\end{array}$} \\
\hline Jejunum & $0.211 \pm 0.029$ & $0.168 \pm 0.023$ & -21 & $<0.025$ \\
\hline Ileum & $0.129 \pm 0.031$ & $0.108 \pm 0.012$ & -16 & $<0.05$ \\
\hline
\end{tabular}

* Values are mean \pm SD.

$\dagger$ Difference between means.

$\ddagger$ Probability vs controls.

Table 2. Morphometric parameters measured in 10-d-old pups issued from ethanol-treated mothers and controls

\begin{tabular}{|c|c|c|c|c|}
\hline \multirow[b]{2}{*}{ Parameter } & \multicolumn{2}{|c|}{ Day 10 postpartum* } & \multirow[b]{2}{*}{$\Delta(\%) \dagger$} & \multirow[b]{2}{*}{$p \neq$} \\
\hline & Controls & Ethanol & & \\
\hline Animals $(n)$ & 8 & 8 & & \\
\hline Body wt (g) & $17.3 \pm 2.9$ & $14.4 \pm 0.7$ & -17 & $<0.01$ \\
\hline Liver wt (mg) & $445 \pm 25$ & $392 \pm 16$ & -12 & $<0.005$ \\
\hline Kidney wt (mg) & $188 \pm 16$ & $210 \pm 7$ & +11 & $<0.025$ \\
\hline Intestinal length $(\mathrm{cm})$ & $34.0 \pm 4.8$ & $34.9 \pm 0.9$ & +3 & NS \\
\hline \multicolumn{5}{|l|}{ Intestinal wt (mg) } \\
\hline Jejunum & $360 \pm 40$ & $327 \pm 26$ & -10 & $<0.05$ \\
\hline Ileum & $240 \pm 28$ & $215 \pm 12$ & -12 & $<0.02$ \\
\hline \multicolumn{5}{|l|}{$\begin{array}{c}\text { Intestinal DNA } \\
\qquad(\mathrm{mg} / \mathrm{cm})\end{array}$} \\
\hline Jejunum & $0.203 \pm 0.027$ & $0.179 \pm 0.018$ & -12 & $<0.05$ \\
\hline Ileum & $0.146 \pm 0.024$ & $0.125 \pm 0.003$ & -15 & $<0.005$ \\
\hline
\end{tabular}

$*$ Values are mean $\pm \mathrm{SD}$.

$\dagger$ Difference $v s$ control group.

$\ddagger$ Probability vs control group.
Table 3. Visceral and intestinal parameters measured in 15-dold rats born from ethanol-treated mothers and controls

\begin{tabular}{|c|c|c|c|c|}
\hline \multirow[b]{2}{*}{ Parameter } & \multicolumn{2}{|c|}{ Day 15 postpartum* } & \multirow[b]{2}{*}{$\Delta(\%) \dagger$} & \multirow[b]{2}{*}{$p \ddagger$} \\
\hline & Controls & Ethanol & & \\
\hline Animals $(n)$ & 8 & 8 & & \\
\hline Body wt (g) & $30.2 \pm 4.0$ & $28.7 \pm 1.1 \ddagger$ & -5 & NS \\
\hline Liver wt (mg) & $870 \pm 136$ & $892 \pm 61$ & +2 & NS \\
\hline Kidney wt (mg) & $254 \pm 11$ & $292 \pm 15$ & +14 & $<0.005$ \\
\hline Intestinal length $(\mathrm{cm})$ & $46.0 \pm 1.0$ & $44.7 \pm 1.6$ & +3 & NS \\
\hline \multicolumn{5}{|l|}{ Intestinal wt (mg/cm) } \\
\hline Jejunum & $25.3 \pm 1.5$ & $26.5 \pm 2.8$ & +5 & NS \\
\hline Ileum & $16.5 \pm 2.0$ & $16.2 \pm 1.4$ & -2 & NS \\
\hline \multicolumn{5}{|l|}{ Mucosal wt (mg/cm) } \\
\hline Jejunum & $14.1 \pm 3.0$ & $15.3 \pm 1.6$ & +7 & NS \\
\hline Ileum & $7.8 \pm 1.9$ & $8.4 \pm 0.5$ & +7 & NS \\
\hline \multicolumn{5}{|c|}{ Intestinal DNA $(\mathrm{mg} / \mathrm{cm})$} \\
\hline Jejunum & $0.32 \pm 0.01$ & $0.30 \pm 0.003$ & -6 & NS \\
\hline Ileum & $0.23 \pm 0.03$ & $0.21 \pm 0.02$ & -6 & NS \\
\hline
\end{tabular}

* Values are mean $\pm \mathrm{SD}$

$\dagger$ Difference vs controls.

$\ddagger$ Probability $v s$ controls.

with hematoxylin and eosin. Morphometric measurements were performed with a Visopan calibrated microscope (Reichert Scientific Instruments, Buffalo, NY). For electron microscopy, small pieces of the proximal jejunum (Treitz) were fixed directly in $2 \%(\mathrm{vol} / \mathrm{vol})$ glutaraldehyde in $0.1 \mathrm{M}$ cacodylate buffer, $\mathrm{pH}$ 7.1 , and postfixed in $1 \%$ osmium tetroxide. After dehydration, they were embedded in the mixture described by Spurr (16). Ultrathin sections stained with uracyl acetate and lead citrate were examined with a Philips EM-301 electron microscope (Philips, Eindhoven, the Netherlands).

Intestinal enzyme assays. Sucrase, neutral lactase, and maltase activities were assayed by the method of Messer and Dahlqvist (17).

Mucosal protein was determined by the method of Lowry et al. (18). Disaccharidase activities were expressed as $\mu \mathrm{mol}$ of substrate hydrolyzed per min and per g protein. Aminopeptidase was assayed according to Maroux et al. (19) using L-alanine-pnitroanilide as substrate. One unit equals $1 \mu \mathrm{mol}$ of $p$-nitroanilide formed per min per $\mathrm{g}$ protein.

Incorporation of $\left.{ }^{3} \mathrm{H}\right]$ thymidine into $D N A$. For the determination of DNA synthesis rates in the jejunum and ileum, $2 \mu \mathrm{Ci} / \mathrm{g}$ body weight of $\left[6-{ }^{3} \mathrm{H}\right]$ thymidine (sp act $23 \mathrm{Ci} / \mathrm{mmol}$; The Radiochemical Center, Amersham, UK) were injected intraperitoneally into each animal $24 \mathrm{~h}$ before the animal was killed. All the injections were given at the same hour of the day to circumvent circadian periodicity in DNA synthesis $(20,21)$. The animals were killed after $24 \mathrm{~h}$, allowing sufficient time for absorption and uniform distribution of the label. Tissue samples $(100 \mathrm{mg})$ of jejunal and ileal mucosa were homogenized in $8 \mathrm{~mL}$ of $0.25 \mathrm{~N}$ cold perchloric acid and assayed by the diphenylamine method of Burton (22) as modified by Giles and Myers (23). Polymerized calf thymus DNA (Grade IV, Sigma Chemical Co., St. Louis, MO) was used as standard. The amount of $\left[6-\mathrm{H}^{3}\right]$ thymidine incorporated into mucosal DNA was determined by counting 1 $\mathrm{mL}$ of the extract in a Beckman liquid scintillation spectrometer. Two samples were taken from each segment, and DNA extracts were counted in triplicate. Results of DNA synthesis rates were expressed in cpm per mg of mucosal DNA.

Zonal distribution of liver enzymes. Immediately after death, the liver was removed and small pieces of $0.5 \mathrm{~cm}$ diameter were cut and frozen in tissue-preserving compound (Cryomatrix, HVL, Brussels, Belgium) by progressive cooling on a metallic cylinder partly immersed in liquid nitrogen (24). Ten- $\mu \mathrm{m}$ frozen sections of liver were cut at $-30^{\circ} \mathrm{C}$ in a Shandon cryostat (HVL) and immediately used for cytochemical assays (24). Optimal conditions for each cytochemical reaction have been published 
Table 4. Incorporation of $\left[{ }^{3} H\right]$ thymidine into mucosal DNA in jejunum and ileum of alcohol offspring and control rats

\begin{tabular}{|c|c|c|c|c|c|c|c|c|}
\hline \multirow[b]{2}{*}{$\begin{array}{c}\text { Age } \\
\text { (d postpartum) }\end{array}$} & \multicolumn{4}{|c|}{ Jejunum } & \multicolumn{4}{|c|}{ Ileum } \\
\hline & $\begin{array}{c}\text { Alcohol* } \\
(n=8)\end{array}$ & $\begin{array}{l}\text { Controls* } \\
(n=8)\end{array}$ & $\% \dagger$ & $p \ddagger$ & $\begin{array}{c}\text { Alcohol* } \\
(n=8)\end{array}$ & $\begin{array}{c}\text { Controls* } \\
(n=8)\end{array}$ & $\% \dagger$ & $p \neq$ \\
\hline 5 & $868 \pm 296$ & $1301 \pm 254$ & -34 & $<0.01$ & $1157 \pm 336$ & $1441 \pm 217$ & -20 & $<0.05$ \\
\hline 10 & $568 \pm 161$ & $745 \pm 200$ & -24 & $<0.05$ & $684 \pm 361$ & $873 \pm 149$ & -22 & $<0.05$ \\
\hline 15 & $568 \pm 164$ & $624 \pm 141$ & -9 & NS & $637 \pm 90$ & $696 \pm 98$ & -9 & NS \\
\hline
\end{tabular}

* Data are mean $\pm \mathrm{SD}$ expressed as cpm $/ \mu \mathrm{g}$ mucosal DNA.

$\dagger$ Variation in percent compared to control values.

$\ddagger$ Probability $v$ s control values.
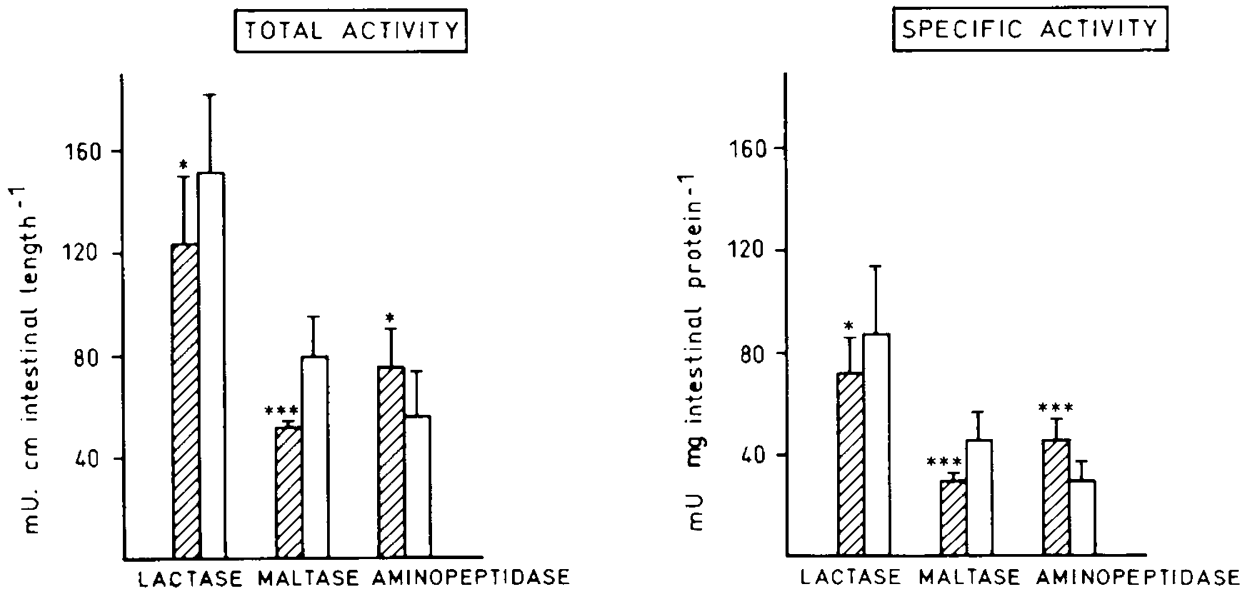

Fig. 1. Changes in the total and specific activity of microvillous enzymes (maltase, lactase, and aminopeptidase) measured in the jejunum of ethanol offspring and controls by d 5 postpartum. Each value represents the mean \pm SD of eight to 10 individual observations. ${ }^{*}, p<0.05 ;{ }^{* * *}, p<$ $0.01 \mathrm{vs}$ controls.

previously in adult and growing rat livers $(24,25)$ and in a rat model of toxic $(\mathrm{CCl} 4)$ cirrhosis $(26)$. For each enzyme reaction, duplicate cryosections were incubated in the appropriate medium containing substrate, cofactors, electron carriers, tissue stabilizers, and inhibitors. For NADPH-dehydrogenase, the incubation medium was a glycylglycine buffer, pH 7.9, $\mathrm{NADPH}_{2} 3 \mathrm{mM}$, and nitroblue tetrazolium $2.45 \mathrm{mM}$. Incubations were performed at $37^{\circ} \mathrm{C}$ in plastic rings for $8 \mathrm{~min}$. The reactions were terminated by washing the slides in running water and by rinsing them in distilled water. The end product was nitroblue tetrazolium redpurple formazan. For glucose-6-phosphatase, the incubation medium was an acetate buffer $0.1 \mathrm{M}$, pH 6.5, glucose-6-phosphate $2.08 \mathrm{mM}$ and $\mathrm{PbNO}_{3} 2.4 \mathrm{mM}$. The reaction was carried out in a Coplin jar at $37^{\circ} \mathrm{C}$ for $6 \mathrm{~min}$ and stopped by washing the slides in running water. Slides were then incubated for $15 \mathrm{~s}$ at room temperature in sulfide water to convert the lead phosphate formed into colored lead sulfide and rinsed in water. After drying, all the sections were mounted in Aquamount medium (BDHGurr, Pasture, Brussels, Belgium) and stored in the dark until density reading. The specificity of each reaction was assayed by including inhibitors in the medium and by heat inactivation (24). The colored end product of the reaction was measured by microspectrophotometry using a Vickers M85 scanning and integrating microdensitometer (Vickers Instruments, York, UK).

The nitroblue tetrazolium formazans were measured at the isosbestic wavelength of $585 \mathrm{~mm}$ and lead sulfide at $510 \mathrm{~nm}$ (24). Measurements were confined to cells located along portal sinusoids, and no reading was done in the septal sinusoids within each zone. The mean integrated density measured was converted into mean integrated extinction units. This standardized unit, reflecting enzyme activity per unit area, was calculated by comparing the density of the specimen with the density of a filter of known extinction value equal to 1 , as previously described (24, 25). To avoid decimals, mean integrated extinction units were multiplied by 100 .

Calculations and statistical analysis. All data are given as mean $\pm \mathrm{SD}$. Intestinal enzyme activities were expressed in both specific and total units per $\mathrm{cm}$ of intestinal length, removing the possibility of an artifact when activities are related solely to protein concentration.

Differences between means were tested for statistical significance $(p<0.05)$ by analysis of variance and unpaired $t$ test.

\section{RESULTS}

During the period of ethanol induction ( $4 \mathrm{wk})$, the amount of calories provided from ethanol expressed as percentage of total calorie intake increased progressively from 26 to $33 \%$. These animals consumed $25 \% \mathrm{vol} / \mathrm{vol}$ in tap water without significant changes in body weight or calorie and liquid intake compared with matched controls. After parturition, pregnant females exposed to ethanol had a higher daily calorie intake (mean $41.2 \pm$ 0.6 versus $37.0 \pm 1 \mathrm{kcal} / \mathrm{d}$, controls, $p<0.05$ ) and their daily body weight gain remained similar to controls. Before delivery, mean alcoholemia was $410 \pm 120 \mathrm{mg} / \mathrm{L}(0900 \mathrm{~h})$. Neonatal mortality was much higher in offspring issued from ethanol-fed mothers than in controls. Among the 38 pups born from five ethanol-fed mothers, 11 were stillborn $(28.9 \%)$ and 27 remained alive, whereas in the control group of 40 pups issued from five control mothers no mortality was recorded. Stillborn pups exhibited a profound dysmature aspect, and at autopsy some of them had birth defects (urinary tract malformations in two pups). At $5 \mathrm{~d}$ (Table 1) and $10 \mathrm{~d}$ (Table 2) postpartum, ethanol offspring showed decreased values of body weight, intestinal weight, and liver weight compared with controls, whereas intestinal length was little changed. Expressed per $\mathrm{cm}$ of intestinal length, jejunal and ileal, DNA concentrations were lower $(-12$ to $-21 \%, p<$ 0.05 versus controls) in pups exposed to ethanol than in controls. These parameters became similar to control values by d 15 (Table 3). Similarly, DNA synthesis rate measured by the incorporation of $\left[{ }^{3} \mathrm{H}\right]$ thymidine into mucosal DNA (Table 4) was depressed in the jejunum and ileum of ethanol pups at 5 and $10 \mathrm{~d}$ of age but 


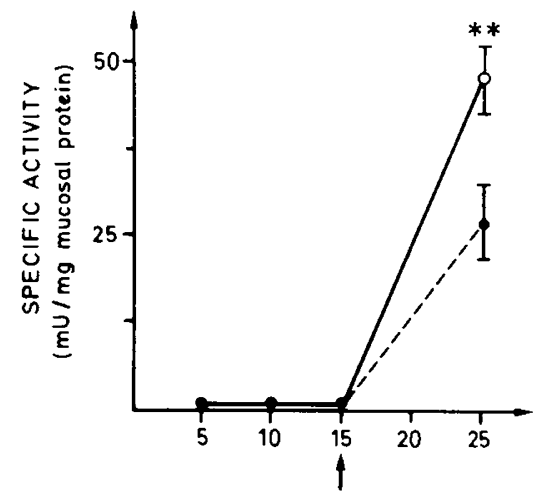

JEJUNUM

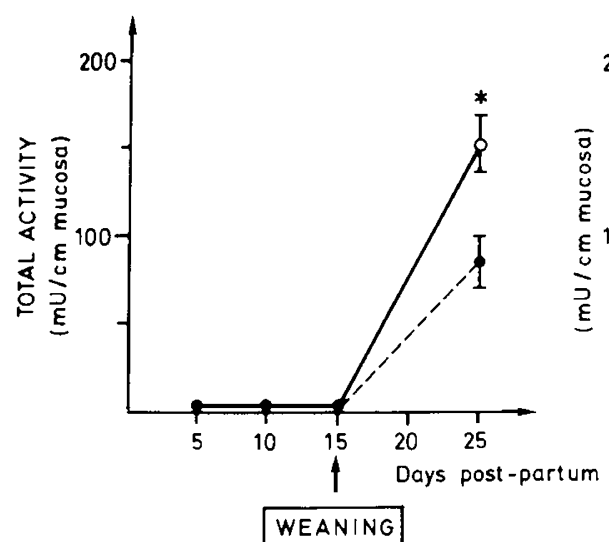

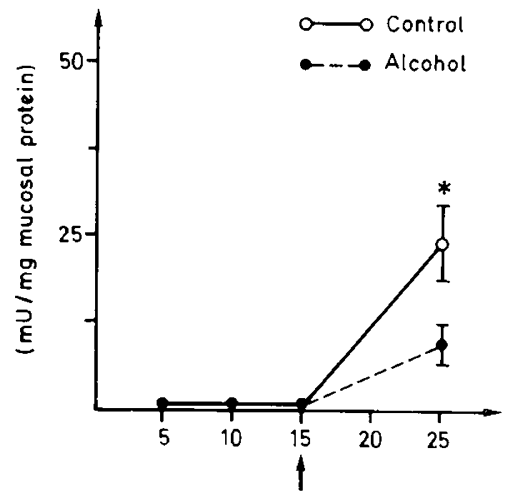

ILEUM

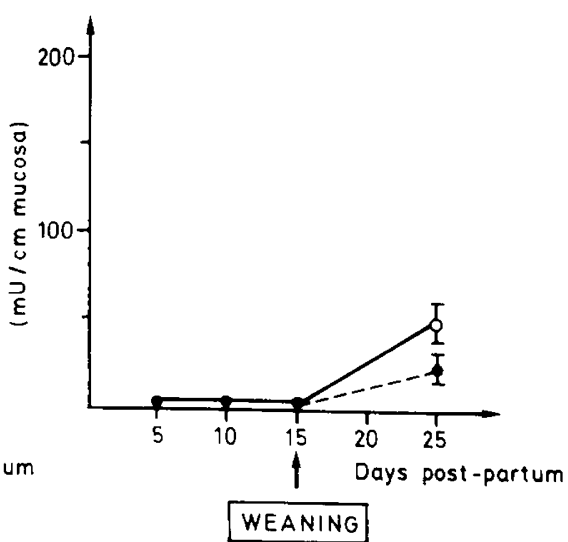

Fig. 2. Ontogenic changes in sucrase activity at weaning in the jejunum and ileum of ethanol offspring and controls. Each value represents the mean $\pm \mathrm{SD}$ of eight to 10 individual observations. *, $p<0.05 ;{ }^{* *}, p<0.02$ vs controls.
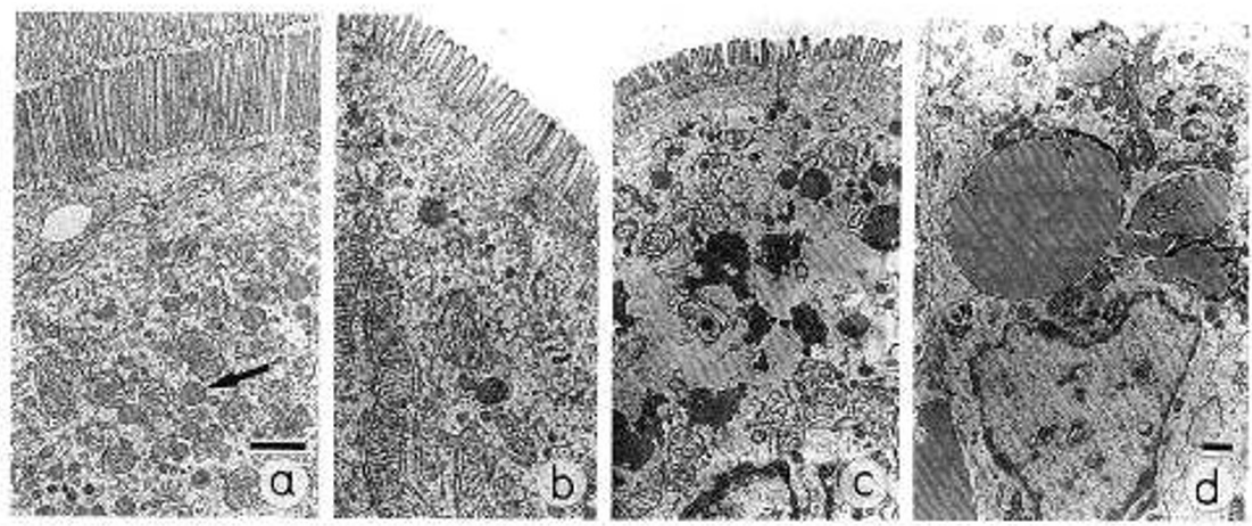

Fig. 3. Ultrastructure of jejunal absorptive cells at the age of $10 \mathrm{~d}$. $a$, Control rat. Note normal density and length of the microvilli and the presence of secretory granules at the apical pole of the cell (arrow). $b$, Common aspect of enterocytes after prenatal exposure to ethanol. Microvilli are sparse and shorter, and secretory granules are much smaller than in controls. $c$, Extreme immaturity of some absorptive cells after prenatal exposure to ethanol with overload in lipids. $d$, Lipids (neutral) accumulate mostly at the basal pole of the cell. $B a r=1 \mu \mathrm{m} ; a, b$, and $c$ at the same magnification.

had returned to control values by $\mathrm{d} 15$. Figure 1 illustrates the effects of prenatal exposure to ethanol on the specific and total activities of several intestinal hydrolases.

After in utero exposure to ethanol, neutral lactase and maltase were diminished by d 5 ( -18 to $-32 \%, p<0.05$ versus controls), whereas aminopeptidase was found to be increased $(+46 \%, p<$ 0.01 ). These enzyme activities did not significantly differ from control values by $\mathrm{d} 10$. The ontogenic decline in neutral lactase occurred at weaning with the same timing in both experimental and control groups (data not shown). As shown in Figure 2, sucrase activity remained virtually absent throughout the nursing period and the ontogenic rise in the enzyme occurred at weaning with the same chronology in both groups. However, in the jejunum as well as in the ileum, the level reached by the enzyme at $\mathrm{d} 25$ was about $50 \%$ lower in ethanol-exposed rats than in controls $(-45$ to $-59 \%, p<0.05$ versus controls). Thereafter, the enzyme activity reached the control values by $\mathrm{d} 35$.

Analysis by electron microscopy of jejunal mucosal samples 
taken at 5,10, and $15 \mathrm{~d}$ of age (Fig. 3 ) revealed that ethanol pups differed from controls by a "fetal-like" immature aspect of the enterocytes that persisted up to d 15 postpartum. Relevant findings included sparse and shortened microvilli, excessive lysosomal structures, marked intracellular steatosis, and paucity of transport vesicles. These changes disappeared at weaning, and by d 25 intestinal ultrastructure appeared to be similar in both groups of animals. Compared to enterocytes, hepatocytes from infant pups seemed little affected by prenatal exposure to ethanol.

Regarding the liver ultrastructure, the only relevant finding was a moderate intracellular steatosis, which persisted in ethanol dams until weaning. Furthermore, the acinar distribution (periportal to perivenular ratio) of the microsomal enzymes glucose6-phosphatase and NADPH-dehydrogenase was unaltered by prenatal exposure to ethanol, and differences in these enzyme activities between ethanol pups and controls during postnatal development were slight and not significant (Fig. 4).

\section{DISCUSSION}

Previous experimental studies have shown that ethanol intake during pregnancy can reproduce some of the alterations observed in the offspring of chronic alcoholic women $(5,27)$. These alterations include a decrease in fetal viability, an increase in neonatal mortality, and reduced fetal and neonatal body weight and brain weight as well as severe neurochemical and hormonal disturbances $(27,28)$. Using a similar experimental model of ethanol administration, the present study demonstrates that postnatal maturation of the small intestine in the ethanol offspring was depressed during the early nursing period, even though ethanol had been withdrawn at birth. Pups born from ethanolexposed mothers differed from matched controls by lower intestinal mass, depressed jejunal and ileal DNA contents per unit of length, decreased mucosal DNA synthesis rate, and by an im-
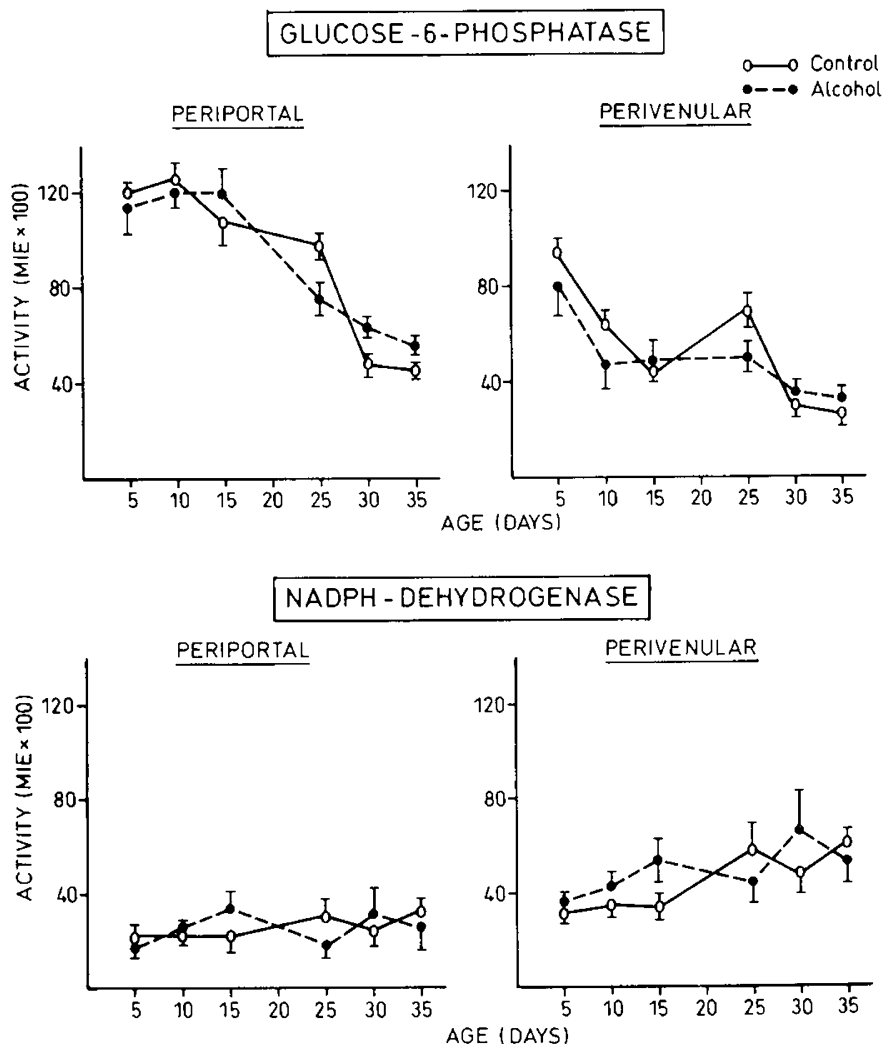

Fig. 4. Acinar distribution and postnatal changes in the activity of microsomal enzymes (glucose-6-phosphatase and NADPH-dehydrogenase) measured in the liver of ethanol offspring and controls. Each value is the mean $\pm \mathrm{SD}$ of 10 individual observations. $M I E$, mean integrated extinction. mature aspect of the enterocytes that persisted until weaning. Alterations in intestinal DNA synthesis and in cell kinetics arising through ethanol administration have been documented by several studies in adult rats $(29,30)$ but not in sucklings exposed to ethanol in utero. Diets containing ethanol at $36 \%$ of total calorie intake for up to 4 wk led to shortening of villi with reduced cellularity and to inhibition of mitotic index and crypt cell production in the jejunum as well as in the ileum $(29,30)$. These intestinal changes have been generally attributed to a direct local cytotoxicity of ethanol or of its metabolites, inasmuch as the same effects can be reproduced by parenteral administration of ethanol without change in feeding cycles (31).

Changes in the specific and total activity of lactase and maltase paralleled those occurring in intestinal mass and mucosal DNA synthesis with significantly decreased enzyme activities at $5 \mathrm{~d}$ postpartum and return to normal values by $\mathrm{d} 15$. Postnatal maturation of intestinal enzymes in rats is characterized at weaning ( $\mathrm{d} 14-21)$ by a shift between lactase and sucrase activities (32). Between d 14 and 21, lactase activity, which remains high during the nursing period, suddenly declines to reach adult levels, whereas sucrase activity, which is virtually absent before weaning, does appear. It is now well established that these ontogenic events are under genetic and hormonal control and can be triggered by exogenous administration of glucocorticoids, insulin, and thyroxine (32-35). Prenatal exposure to ethanol did not disturb the ontogenic timing of sucrase maturation or the normal decline of lactase at weaning, indicating that ethanol in utero did not affect the processes regulating these events. However, the level reached by sucrase activity at $\mathrm{d} 25$ was lower in ethanol offspring than in controls. This could be a result of delayed maturity because it has been shown that the final step of sucrase maturation is highly dependent upon age, diet, and body weight $(36,37)$. Recently, Raul et al. (38) found that the specific activity of lactase and sucrase were slightly but not significantly decreased in the brush border membrane of offspring from ethanol-fed mothers at $2 \mathrm{wk}$ postpartum. However, these authors did not study changes in brush border membrane enzymes during the early nursing period at 5 and $10 \mathrm{~d}$ postpartum.

In contrast to the small intestine, the ultrastructure of the liver was normal except for moderate steatosis. Furthermore, the zonal activities and postnatal development of the two microsomal enzymes NADPH-dehydrogenase and glucose-6-phosphatase were unaffected by in utero exposure to ethanol. These enzymes were chosen because they represent major metabolic pathways in the liver of the neonate. Interestingly, the perivenular activity of glucose-6-phosphatase was preserved even though the enzyme is highly sensitive to toxic substances (26) and ethanol may produce perivenular cell damages.

Similarly, NADPH-dehydrogenase, an enzyme of the microsomal oxidative system that prevents the formation of toxic free radicals, was not induced by exposure to ethanol. Because metabolic zonation, which is expressed by the ratio of periportal to perivenular activity, was similar in control and ethanol pups, it can be concluded that the functional heterogeneity of hepatocytes was preserved in the ethanol offspring.

In chronic ethanol-fed rats, Sanchis et al. (8) reported that, except for glutamate dehydrogenase, microsomal and alcohol metabolizing enzymes remained unchanged in the liver as well as in placenta of the mothers, even though their progeny was severely affected in morbidity and mortality. Thus, it appears that fetal organs may be damaged with a variable degree of severity according to their metabolism and sensitivity to ethanol.

In conclusion, the present data indicate that exposure to ethanol during pregnancy can affect the postnatal development of the small intestine, whereas the ultrastructure and enzyme maturation of the liver are preserved. Consequently, alteration by ethanol of intestinal functions originating in utero could play an important role in the development of failure to thrive and malnutrition observed in infants with FAS. 
Acknowledgments. The authors thank J. Toth, N. De Keyser, T. T. Muller, and E. Colette for expert technical assistance and Dominique Vermeulen for preparation of the manuscript.

\section{REFERENCES}

1. Mezey E 1975 Intestinal function in chronic alcoholism. Ann NY Acad Sci $252: 215-227$

2. Baraona E 1974 Small intestinal damage and changes in cell population produced by ethanol ingestion in the rat. Gastroenterology 66:226-234

3. Lieber CS 1988 Biochemical and molecular basis of alcohol induced injury to liver and other tissues. N Engl J Med 319:1639-1650

4. Jones KL, Smith DW 1983 Patterns of malformation in offspring of chronic alcoholic mothers. Lancet 1:1268-1271

5. Clarren SK, Smith DW 1978 Fetal alcohol syndrome. N Engl J Med 298:10631067

6. Abel EL 1982 Consumption of alcohol during pregnancy: a review of effects on growth and development of offspring. Hum Biol 54:421-453

7. Manzke H, Grosse FR 1982 Incomplete and complete alcohol syndrome: three children of a female drinker. Med Welt 26:709-712

8. Sanchis R, Sancho-Tello M, Chirivella M, Guerri C 1987 The role of materna alcohol damage on ethanol teratogenicity in the rat. Teratology 36:199-208

9. Streissguth AP, Landesman-Dwyer S, Martin JC, Smith DW 1980 Teratogenic effects of alcohol in humans and laboratory animals. Science 209.353-361

10. Hanson JW, Streissguth AP, Smith DW 1978 The effects of moderate alcohol consumption during pregnancy on fetal growth and morphogenesis. J Pediatr 92:457-460

11. Sanchis RM, Sancho-Tello M, Guerri C 1986 The effects of chronic alcohol consumption on pregnant rats and their offspring. Alcohol Alcohol 21:295305

12. Ansel EL, Dintcheff BA 1978 Effects of prenatal alcohol exposure on growth and development in rats. J Pharmacol Exp Ther 207:916-92

13. Merlin L 1987 Early fetal growth and development in mice chronically exposed to ethanol during gestation. Growth 51:146-153

14. Testar X 1986 Ethanol administration in the drinking fluid to pregnant rats as a model for the fetal alcohol syndrome. Pharmacol Biochem Behav 24.625630

15. Saito M, Kaito $H$, Suda $H 1980$ Circadian rhythm of intestinal disaccharidases of rats fed with a diurnal periodicity. Am J Physiol 238:G77-G101

16. Spurr AR 1969 A low-viscosity epoxy resin embedding medium for electron microscopy. J Ultrastruct Res 26:31-43

17. Messer M, Dahlqvist A 1966 A one step ultramicromethod for the assay of intestinal disaccharidases. Anal Biochem 14:376-392

18. Lowry OH, Rosebrough NJ, Farr AL, Randall RJ 1951 Protein measurement with the Folin phenol reagent. J Biol Chem 193:265-275

19. Maroux S, Louvard D, Baratti J 1973 The aminopeptidase from the dog intestinal brush border. Biochim Biophys Acta 321:282-295

20. Buts JP, De Meyer R, Kolanowski J 1983 Ontogeny of cell proliferation and DNA synthesis in rat colon: role of glucocorticoids. Am J Physiol 244:G469G474
21. Sigdestad CP, Bauman J, Lesher SW 1969 Diurnal fluctuations in the number of cells in mitosis and DNA synthesis in the jejunum of the mouse. Exp Cell Res 58:159-162

22. Burton KA 1956 A study of the conditions and mechanisms of the diphenylamine reaction for the calorimetric estimation of deoxyribonucleic acid Biochemistry 62:315-323

23. Giles KW, Myers M 1965 An improved diphenylamine method for the estimation of DNA. Nature 206:93-94

24. Sokal EM, Trivedi P, Cheeseman P, Portmann B 1989 The application of quantitative cytochemistry to study the acinar distribution of enzyme activities in human liver biopsy specimens. $J$ Hepatol 9:42-48

25. Sokal EM, Trivedi P, Portmann B, Mowat AP 1990 Adaptive changes of metabolic zonation during the development of cirrhosis in growing rats. Gastroenterology 99:785-792

26. Sokal EM, Trivedi P, Portmann B, Mowat AP 1989 Developmental changes in the intra-acinar distribution of succinate dehydrogenase, glutamate dehydrogenase, glucose-6-phosphatase and NADPH dehydrogenase in the rat liver. J Pediatr Gastroenterol Nutr 8:522-527

27. Guerri C, Esquifino A, Sanchis R, Grisolia S 1984 Growth enzymes and hormonal changes in offspring of alcohol-fed rats. In: Mechanism of Alcohol Damage In Utero. Ciba Foundation Symposium 105, Pitman, London, 105, pp 85-102

28. Sanchis R, Guerri C, Renau-Piqueras J, Grisolia S 1984 Effects of prenatal and postnatal alcohol intake on brain development. In: Caciagli F, Giacobini E, Padetti R (eds) Developmental Neuroscience Physiological Pharmacological and Clinical Aspects. Elsevier, Amsterdam, pp 217-223

29. Lansdown ABG, Dayan AD 1987 Alterations in crypt cell populations in the small intestine as an early toxic response to subacute ethanol administration. Arch Toxicol 59:448-452

30. Mazranti R, Debnam ES, Jenkins WJ, McIntyre N 1985 Chronic alcohol ingestion decreases the enterocyte turnover: a possible intestinal adaptation in rats. Gastroenterology 88:1494-1499

31. Clarke DW, Steenaart NAE, Bredon TH, Brien JF 1985 Differential pharmacokinetics for oral and intraperitoneal administration of ethanol to the pregnant guinea pig. Can J Physiol Pharmacol 63:169-172

32. Henning SJ 1981 Postnatal development: coordination of feeding, digestion and metabolism. Am J Physiol 241:G199-G214

33. Buts JP, De Keyser N, Kolanowski J, Van Hoof F 1990 Hormonal regulation of the rat small intestine: responsiveness of villus and crypt cells to insulin during the suckling period and unresponsiveness after weaning. Pediatr Res 27:161-164

34. Doell RG, Kretchmer N 1964 Intestinal invertase: precocious development of activity after injection of hydrocortisone. Science 143:42-44

35. Yeh KY, Holt PR 1986 Ontogenic timing mechanism initiates the expression of rat intestinal sucrase activity. Gastroenterology 90:520-526

36. Buts JP, Vamecq J, Van Hoof F 1986 Alteration of intracellular synthesis of surface membrane glycoproteins in small intestine of iron-deficient rats. Am J Physiol 251:G736-G743

37. Gall DG, Chung M 1982 Effect of body weight on postnatal development of the proximal small intestine of the rabbit. Biol Neonate 42:159-165

38. Raul F, Ledig M, Gosse F, Galluser M, Duffoel M 1987 Prenatal exposure to alcohol in rats: effects on intestinal enzymes in offspring. Alcohol 4:405-408 